\title{
JULIUS PREUSS
}

\author{
by
}

\section{FRED ROSNER*}

THE OLDEST known Hebrew medical writing is that of Asaph which dates from the seventh century. ${ }^{1}$ Since the ancient Hebrews left us no specific medical texts, our only sources of knowledge on this subject are the medical and hygienic references found in the Jewish sacred, historical, and legal literatures. ${ }^{2}$ It is from these that the fragments of our knowledge of their medical views and practices have been gathered. The difficulty has been great, for the material is scant and its meaning often uncertain; the period which these sources cover is very long. Much of the material is "popular medicine"; most, if not all, was transmitted by laymen.

The first systematic studies of the medicine of the Bible were published early in the seventeenth century, among the first fruits of the study of the Bible awakened by the Reformation. The earlier books dealt only with the Old and the New Testaments (with the single exception of the dissertation of Gintzburger of 1743). It was not until the nineteenth century that studies included the Talmud and other ancient Hebraic writings. ${ }^{3}$

The literature that has grown up during the past three centuries is very extensive; much of it deals with special subjects; much embraces studies limited to single works such as the Talmud. As would be expected, these studies reflect the scientific spirit of their period, the uncritical or the critical attitude of the Biblical scholars, and the current views on medicine. The writers have, for the most part, been Biblical students ; others were students of medical history; there are a few who were both. R. J. Wunderbar, who completed his Biblisch-Talmudische Medizin in 1860, was a layman. Wilhelm Ebstein, whose writings appeared in 1901 (Die Medizin im Alten Testament, Stuttgart, Enke) and 1903 (Die Medizin in Neuen Testament und im Talmud, Stuttgart, Enke) was dependent upon the use of available fragmentary translations. Other works concerning all of Biblical-Talmudical medicine did not exist. It was not until the publication of Julius Preuss'Biblisch-Talmudische Medizin in 1911 that we acquired a reliable, comprehensive, and scholarly exposition of the subject by a first-class physician on the one hand, and a thorough semitic philologist, who made the history of medicine his life's study, on the other."

Julius Preuss (Figure 1) was born on 5 September 1861 in the small village of Gross-Schoenbeck near Potsdam in Uckermark, Germany. ${ }^{5}$ His was the only Jewish family in the village. Young Preuss attended the public schools in the town of Angermunde and then entered the Gymnasium in Prenzlau, where he distinguished

*Fred Rosner, M.D., F.A.C.P., Director of Hematology, Queens Hospital Center, Affiliation of the Long Island Jewish-Hillside Medical Center; and Associate Professor of Medicine, Health Sciences Center, State University of New York at Stony Brook, U.S.A. 


\section{Julius Preuss}

himself by his brilliant scholarship. Upon graduation, he went to study medicine at the University of Berlin, where he completed the course of study in 1886 with a doctoral thesis entitled "Concerning syphilis as the etiology of tabes dorsalis and dementia paralytica". The newspapers contained an interesting account of the brilliant young doctor who achieved the rare feat of having passed Rudolph Virchow's examination with the highest marks. ${ }^{6}$ Virchow, the founder of cellular pathology, was a highly versatile personality known for his uncompromisingly exacting standards. He paid Preuss the extreme compliment of telling him that his way of thinking was that of a true physician: Sie koennen medizinisch denken. ${ }^{7}$ Preuss returned to his native town to practise medicine, but in 1891 went back to Berlin where he was a general medical practitioner and where he studied and wrote.

According to Muntner, ${ }^{8}$ Preuss lived in an age which saw the resurgence of the critical approach in scientific as well as historical research. He was a part of the century which gave to the Jewish world Solomon Judah Rapoport (1790-1867) and Leopold Zunz (1794-1886), the pioneers of the "Science of Judaism"; the literary historians Leopold Dukes (1810-1891) and Abraham Berliner (1833-1915); scholars like David Cassel (1818-1893), Abraham Geiger (1810-1874), Moritz Guedemann (1835-1918), David Kaufmann (1852-1899), Mayer Moritz Kayserling (1829-1905), Isidore Loeb (1839-1892) and, of course, Heinrich Graetz (1817-1891), the author of the classic history of the Jews. Towering above all these luminaries was Moritz Steinschneider (1816-1907), the orientalist and bibliographer who, in addition to other ancient source material, unearthed a wealth of data on the history of Jewish research in the sciences, including medicine.

Historical literature in the field of medicine could boast of a number of impressive works, including those of Haeser, Henschel, Neuburger and Pagel. Sadly lacking, however, was reliable and critical research in the field of Jewish medicine. To be sure, continues Muntner, there was no dearth of general essays on medicine in Biblical and even Talmudic times, but most of these were superficial, unscientific and, occasionally, like those written by Carmoly (1802-1875), of dubious authenticity. Even the few outstanding works that appeared such as those of Bergel, Holub, Rabinowitz, Wunderbar and Ebstein, fell far short of the analytical approach which characterized the writing of Julius Preuss.9

Preuss was a physician of fine training and wide experience, a learned scholar in Hebrew literature as well as in medical and general history. He studied Talmud with the famous Rabbi Ritter, later Chief Rabbi of Rotterdam, never having attended a Jewish school in his youth. Preuss's unusual Hebraic background, his vast knowledge of Jewish thought and Hebrew literature, and his scientific method, make his book Biblisch-Talmudische Medizin the authoritative work on the subject to this very day.

In 1961, to commemorate the one-hundredth anniversary of the birth of Julius Preuss and the fiftieth anniversary of the appearance of his magnum opus, a variety of meetings and lectures were held, and numerous articles and essays published.10 Leibowitz ${ }^{11}$ decries the lack of available detailed information concerning the life of Preuss and points out that Rabbi Joseph Carlebach, last Chief Rabbi of Hamburg and son-in-law of Preuss, said that Preuss used to read the book of Psalms and study the Mishnah when he travelled to and from his patients in neighbouring towns, so 


\section{Fred Rosner}

that after a while he learned them by heart. Preuss turned to the renowned Rabbi Hildesheimer for legal Judaic opinions concerning medical matters, such as remuneration for Sabbath visits to the sick. Preuss's return to Berlin in 1891 was precipitated either by his desire to be surrounded by learned scholars and academicians ${ }^{12}$ or by the great difficulties in the observance of traditional Judaism which he encountered in his small native village.

Preuss was a very successful physician and his practice grew considerably. He married Martha (Rachel) Halberstadt from Hamburg late in 1899 or early in 1900. They had three children, two daughters and one son. One daughter and her husband Rabbi Carlebach were killed in World War II; two of their daughters now reside in Israel, one son lives in England, and one son lives in New York. A second daughter of Preuss, married to Felix Goldschmidt of Jerusalem, died in 1966 leaving five children, all residing in Israel. Julius Preuss's son, Jacob, lives with his wife in Herzliya, Israel. Their four children are also residents of the Jewish state. Julius Preuss's wife died in Israel in 1960.

Preuss himself became ill in 1911 when his Biblisch-Talmudische Medizin first appeared, although he had already written to Immanuel Löw in 1898 expressing his fear that he would not be able to complete his work because of ill health. His fatal illness is variously described as "a lung abscess which probably could have been controlled by chest surgery and/or antibiotics which were not available in his lifetime"1s or "cancer of the throat, complicated by tuberculosis and bronchiectasis". 14

He died on 23 September 1913 at the early age of fifty-two and was buried in the Adath Israel cemetery in Berlin. He was not eulogized at his funeral, according to his own wishes. His tombstone bears the simple epitaph: rophé, velo lo, "physician, but not for himself". The humility of Preuss is also exemplified by the title which appears beneath his name in all editions of his book: Julius Preuss, Arzt in Berlin, "physician in Berlin".

Sudhoff said the following about Preuss:

... in the one hour that we were together, he permitted me, the non-Jew, to see so deeply into his soul, that I knew his hope was to be a classical philologist-this man, whose practical course of life made his dream impossible because he was a Jew. He had become a physician and his remarkable talent for historical and philological investigation directed him to the study of the history of his specialty as an avocation, and in particular to that branch which inevitably attracts every Jewish physician of the old stamp; namely, Biblical and Talmudic medicine.

... Julius Preuss never lacked in his work either the inspiration or the devotion so essential to thorough accomplishment. But from inspiration he derived only the incentive which spurred him on to the mastery of difficulties. Never did he permit it to obscure his historical judgment in its incorruptible service toward the establishment and enunciation of truth. Cool to the very heart, he was; love of the people of Israel did not cloud his view. Enthusiasm for their superior viewpoint did not make him see the straight line as crooked. For these very reasons, Dame History has laid laurels upon his grave, as a memorial to him, the master of historic criticism. . . .

\section{PREUSS'S WRITINGS}

I would like to call attention to several little-known yet important articles of Preuss which antedated his Biblical-Talmudical compositions. The first, which was never published, was written in 1885 and is entitled Ueber Untersuchungen des Blutes zu Diagnostischen Zwecken (Bibliography item 34). Another little-known article of 


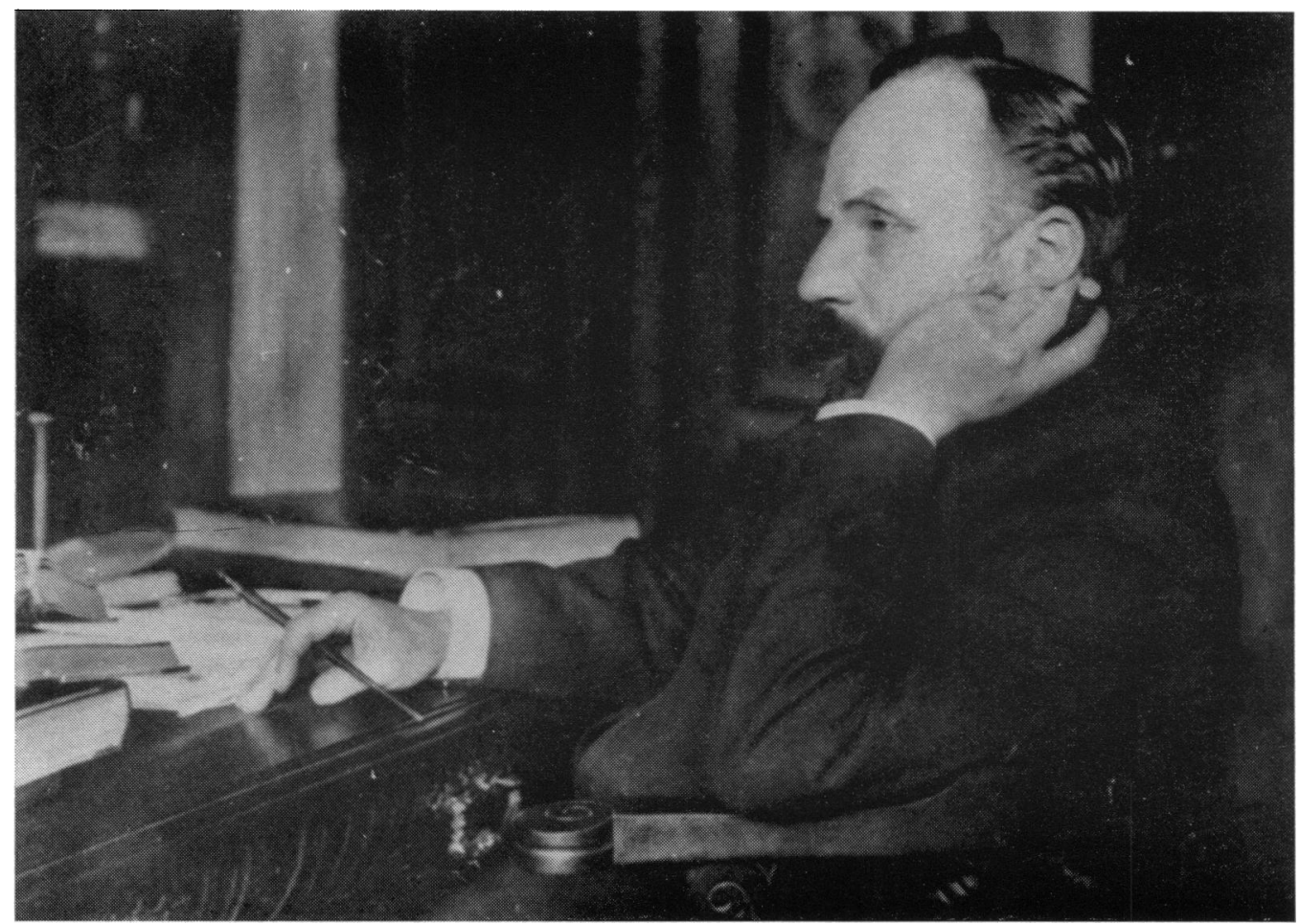

Figure 1.

Julius Preuss (1861-1914). (Reproduced by courtesy of Mr Jacob Preuss, Herzliya, Israel.) 


\section{Julius Preuss}

Preuss entitled Vom Versehen den Schwangeren was published in two different periodicals in 1892 (Bibliography item 2). In this detailed critical-historical study with 211 references, Preuss discusses the possible effect of psychic or psychological impressions of a woman during coitus on her child. Can such psychic influences partially or completely alter the development of the unborn foetus?

Another brief article entitled Zur Pathologie der Zunge (Bibliography item 3) describes two patients, one of whom was a baby with a tumour of the lingual frenulum and the other a woman with chronic superficial glossitis.

Other unpublished articles by Preuss include papers on quackery and secret remedies, domestic hygiene, the position of the woman in Judaism and the duty of Jewish physicians (Bibliography items 35, 36, 37, 38).

Preuss's writings on Biblical and Talmudical medicine began with an article entitled 'Der Arzt in Bibel und Talmud' which was published in 1894 in the prestigious Virchow's Archiv, and was soon reprinted in Hebrew translation (see Bibliography item 4). Numerous other essays on various aspects of Biblical and Talmudical medicine followed in a variety of scientific and literary journals. A complete bibliography concludes this article. Two earlier bibliographies ${ }^{16}$ are incomplete and contain several errors.

The original manuscript of Preuss's magnum opus is today housed in the manuscript and archives section of the Hebrew University library in Jerusalem. ${ }^{17}$ In the Friedenwald collection of Medica-Judaica in the same library, one finds an item called "Notes on Preuss"18 in which the late Dr. Harry Friedenwald of Baltimore took copious notes in English on Preuss's book, chapter by chapter. Interesting is Friedenwald's assertion near the end of his notes that: "I find no chapter on senility in Preuss, not even a paragraph".

Preuss's book is not without imperfections. ${ }^{19}$ Gordon points out that the Jerusalem Talmud was not compiled by Rabbi Yohanan as Preuss asserts because many sages therein lived much later than Rabbi Yohanan. ${ }^{20}$ Rav Ashi is also not the last of the compilers of the Babylonian Talmud, as stated by Preuss. The listing of physicians of the Talmud enumerated by Preuss is incomplete. Numerous other "minor" criticisms are cited by Gordon. ${ }^{21}$ The indices in Preuss's book, particularly the general index, are very sparse.

The shortcomings do not detract from the classic and enduring value of Preuss's work and almost every major medical library, public or private, possesses a copy of Biblisch-Talmudische Medizin. The creation of the State of Israel in 1948 and the renaissance of the Hebrew language have awakened new interest in Biblical and Talmudical writings so that the grandeur of Preuss's contribution is being more and more appreciated by modern scholars. An updating and revision with correction of errors of the work remains a desiratum to this very day. Only four pages of the book (pages 515-519 of the German edition) ${ }^{22}$ and a few excerpts ${ }^{23}$ have been published in English translation.

Karl Sudhoff hailed Preuss's work as one of the most important contributions to the history of medical scholarship in the preceding half-century. ${ }^{24}$ Nothing has happened in the six decades since 1914 to change that assertion. It remains an indispensable work for the student of Hebrew medicine. 


\section{Fred Rosner}

THE 'BIBLISCH-TALMUDISCHE MEDIZIN'

There follows a brief description of Preuss's classic book Biblisch-Talmudische Medizin, which has indelibly recorded its author's name for posterity as a giant in Biblical and Talmudic medical scholarship. Muntner seems fully justified in calling Preuss "the father of Hebrew medical research". ${ }^{25}$ The Biblisch-Talmudische Medizin was originally published in Berlin by S. Karger in 1911 and reprinted unchanged in 1921 and 1923 by the original publisher and in 1969 by Gregg Publishers in England. In 1971, the Ktav Publishing Company in New York reprinted the book unchanged for the fourth time but added an introduction, biographical sketch and bibliography of Julius Preuss by Suessmann Muntner, and a Hebrew and Aramaic register which was prepared in handwritten copy by Adolph Löwinger several years after the original 1911 publication. An English translation of this register by Samuel Paley is also included.

Preuss's work is an anthology of all his articles published over many years in a variety of scholarly journals (see bibliography). In the preface to his book, Preuss points out that the number of commentaries, textbooks and individual works on the Bible is enormous. Preuss's book, covering the entire subject of Biblical and Talmudical medicine, is the first compiled by a physician in which the material is derived directly from the original sources.

In chapter one, entitled "The physician and other medical personnel", Preuss defines the term physician, rophé in Hebrew and asya in Aramaic. He describes the position of the physician in antiquity, his fees, and his responsibilities to his patients. In Judaism, a physician is regarded as a messenger of God. If he intentionally injures a patient, the physician is obviously liable; otherwise he is held blameless. Physicians served as expert witnesses in civil court cases and in the evaluation of a criminal in terms of his capacity to tolerate disciplinary flogging. The physician was and still is consulted regarding the severity of an illness which involves the need to desecrate the Sabbath or the Day of Atonement for the patient.

Preuss describes the education of a physician in ancient times which was accomplished either by the apprenticeship method or in official schools of medicine. He also lists some of the physicians mentioned in the Talmud such as Theodoros, Tobiya, Bar Girnte, Bar Nathan, Rabbi Ammi, and Mar Samuel, the most illustrious of all.

In chapter two, there is an account of the anatomy and physiology of the various body organs and limbs as mentioned in the Bible and Talmud by dividing them into external organs (head, face, chin, neck, shoulder, axilla, elbow, forearm, hand, fingers, thumb, fist, nail, foot, heel, toes, knee, thigh, hips, back and abdomen), organs of sensation (eye, nose, ear, skin) and internal organs. The latter include organs of the digestive system (lips, teeth, oesophagus, stomach, liver, gallbladder, and spleen), respiratory system (lung and voice-box), circulatory system (heart and aorta), genitourinary system (kidneys, urinary bladder and male and female genitalia) and nervous system (brain and spinal cord). Preuss attempts to identify the 248 limbs mentioned throughout early Jewish writings which are said to correspond to the 248 positive commandments of Judaism.

Chapter three begins with a definition of the patient. Preuss then discusses the belief in ancient Judaism that demons cause illness. For example, the Talmud states 
that a mad dog is possessed by an evil spirit. Preuss talks of astrology and the evil eye, of magic and incantations and amulets to ward off disease. Astrological reasons were especially decisive for the selection of days appropriate for bloodletting, not only in Talmudic times, but throughout the centuries and millennia. Rarely found in Talmudic writings is the ancient Greek concept of the four body humours (black bile, yellow bile, phlegm and blood) whereby diseases are thought to occur by their dysequilibrium, with one or the other predominating in the body or in a specific organ.

The fourth chapter, called "Sicknesses and their treatment", begins with a lengthy discussion of plague or pestilence. Preuss lists all the epidemics described in the Bible and Talmud, and concludes that it is not possible, because of the dearth of symptomatology mentioned, to establish with certainty whether or not the numerous Biblical and Talmudical diseases referred to as megepha, deber, nega or negeph represent bubonic plague, cholera, dysentery, typhus or some other epidemic illness. Askara seems to be epidemic diphtheria since it afflicts primarly children, and the major symptoms are referable to the throat. Preuss discusses acute and chronic fevers and describes various remedies, mostly from folk medicine, for quotidian, tertian and quartan fevers. He also lists the causes and remedies for dropsy, gout, heat stroke, and yerakon, which is the Biblical and Talmudical expression for jaundice and/or anaemia. Biblical and Talmudical descriptions of lung maladies such as perforations, defects, lumps, cysts, fistulae and adhesions, as well as mention of digestive tract illnesses such as dysentery, colic, bulimia, haemorrhoids, and intestinal worms are provided by Preuss in this chapter. Finally, the five types of heart ailments are discussed: pain, weakness, heaviness, palpitations and pressure on the heart.

Chapter five is devoted to surgery and deals primarily with injuries and malformations. Preuss begins with a discussion of surgical instruments such as the small drill for opening the skull, the knife for circumcision, needles to remove splinters, and others. He then describes various types of injuries such as sword or other stab or puncture wounds, burn wounds, broken bones, dislocations and sprains, and amputations for gangrene. Also described are injuries inflicted by animals such as the bite of a mad dog, snake bites, insect bites and worm infestation. The signs of a mad dog as mentioned in the Talmud are as follows: its mouth is open, its saliva is dripping, its ears flap, its tail hangs between its thighs and it walks on the edge of the road.

There are two appendices to this chapter. The first deals with circumcision. Preuss discusses some of the boundless literature on the theories of the origin of circumcision, the covenant of Abraham, the importance and technique and timing of circumcision and reasons for its postponement (i.e. illness), the instrumentation used, and circumcision practised by other peoples. A bleeding disorder, perhaps haemophilia, and its transmission may have been recognized, for the Talmud rules that if two children are exsanguinated by circumcision the third child should not be circumcised. Furthermore, if two sisters each had a son who died of bleeding following circumcision, then the third sister should not circumcise her son. Although later Jewish codes assumed that haemophilia can also be transmitted through the baby's father, the secondcentury Talmud correctly recognized the sex-linked nature of this disease; thus, only males have the disease but females are carriers and transmit it to their male offspring. 


\section{Fred Rosner}

The second appendix deals with bloodletting, either for therapeutic reasons or as a preventive measure. The Talmud discusses the frequency, amount, site of bloodletting, and the instrumentation used, including a lancet, a nail or other pointed objects, and cupping glasses. Dietary factors in relation to bloodletting are considered important. Mar Samuel said that a person to be bled should be fasting; after the bloodletting, the patient should tarry a little, then arise and eat a little before going out. The consumption of nourishing foods after bloodletting is essential. Venesection on animals is also discussed.

Surgery of the eye is not considered in the Bible or Talmud, but spectacles, eye prostheses, artificial eyes and eye make-up are described in some detail.

In chapter seven, which deals with dentistry, Preuss discusses toothaches, cavities, loose teeth and artificial teeth. Sour fruit is said to be good for toothache. The vapours of a bathhouse are harmful to the teeth. Vinegar causes loosening of teeth. Preuss points out the emphasis which oriental people place on beautiful teeth.

In the very brief chapter on otology, Preuss describes anatomical defects of the ears, piercing of ears, and other injuries, whether intentionally inflicted or not, pain in the ear, remedies for ear ailments, and deafness and its causes.

In an equally brief chapter on disorders of the nose, Preuss describes various abnormal shapes and disfigurements of the nose, as found in the Bible and Talmud. Nasal polyps are discussed, as well as remedies for nosebleeds, mostly from folk medicine.

Chapter ten is devoted to neurological disorders. About a third of the chapter deals with epilepsy and hysteria. Love-sickness was thought in antiquity to be a type of hysteria. Also discussed in this chapter are headache, plethora and migraine, paralysis, apoplexy, sciatica and the tremor of old age. The Talmud recommends that the head be rubbed with wine, vinegar or oil to treat a headache. Numerous remedies are prescribed for migraine including many from folk medicine.

Mental disorders are covered in chapter eleven. Preuss discusses in detail the mental illness of King Saul of Israel. After considerable deliberation, he concludes that Saul was a "melancholic in the psychiatric sense"; today we would say that he suffered from a paranoid psychosis. His ravings, his affliction with evil spirits, and the stripping-off of his clothes, are interpreted by Preuss to represent epilepsy or an epileptic equivalent. Visual and auditory hallucinations, insanity, "possession by demons or spirits", and exorcism are all cited by Preuss. An imbecile is considered to be mentally deficient and is equated with a minor and a deaf-mute in Jewish law; he cannot testify in court, his contracting of marriage is invalid, etc. The Talmud defines a person who is mentally ill: "He who goes out at night alone, and he who spends the night in a graveyard, and he who tears his garments, and destroys everything that is given to him". ${ }^{26}$ This state is distinguished from an intoxicated individual who behaves like a madman.

In the chapter on skin diseases, Preuss points out that an enormous number of books and treatises have been written about the thirteenth chapter of the book of Leviticus which deals with an illness called tzaraath. As a result, says Preuss: "one might think that every detail would have been clarified and every linguistic and archaeological problem solved. However, just the opposite is the case" (p. 369). 


\section{Julius Preuss}

Preuss discusses the fundamental law of tzaraath, and describes the various skin lesions, scabs, boils, scars, eczema, burn wounds and the like as mentioned in the Bible and Talmud. The diagnosis, treatment and cure of tzaraath are discussed. This disease was thought to represent punishment for the sin of slander. The illness shechin and its various forms, the shechin of Egypt, and the sicknesses of Job and King Hezekiah are also discussed. Preuss concludes that shechin is a collective name comprising many types of skin diseases including inflammatory and traumatic lesions.

There are two appendices to this chapter. The first deals with gonorrhoea, its causes and mode of transmission, and the Jewish ritual laws pertaining to those afflicted with it. In the second appendix, which concerns cosmetics in the Bible and Talmud, Preuss describes haircutting instruments, haircuts and hairstyles for both men and women, hair hygiene, depilatories and wigs. Also discussed are embrocations, oils, perfumes, cosmetics, soaps and facial makeup.

A brief chapter on gynaecology deals primarily with menstruation and its ritual implications, vaginal bleeding and its causes and treatment, and castration in the female. Most remedies are from folk medicine; for example, "give the woman with vaginal bleeding Persian onions boiled in wine or cumin, safflower and fenugreek boiled in wine, and exclaim to her: cease your discharge!" (p. 439).

Chapter fourteen is devoted to obstetrics. The first half of the chapter deals with normal physiological events surrounding pregnancy including the recognition and duration of pregnancy, the foetus and foetal development, sex determination, multiple births, premature births, parturition, the birthstool, the placenta, postpartum ritual purification, the newborn infant, washing, salting and swaddling of the newborn, lactation and suckling, wet-nurses and nursing from an animal or bottle. Of particular interest is the recognition by Mar Samuel in the Talmud that a foetus begins to assume form and shape at forty days after conception. Prior to that time, it is "mere fluid". Also of interest is the "preserving stone" which women carried with them to insure normal pregnancies. Furthermore, the concept of superfecundity, that is one woman becoming pregnant from two men, was accepted in the Talmud.

The second half of the chapter on obstetrics deals with pathological occurrences. Among the subjects discussed are sterility, abortion and the abortus, moles, monster births, false pregnancy, difficult labour and embryotomy, sorcery in obstetrics, caesarian sections and puerperal illnesses. Numerous methods of contraception are discussed in the Talmud but perhaps the most interesting is the "potion of herbs", also known as the "cup of roots". This remedy is prepared from Alexandrian gum, liquid alum and garden crocus, powdered and mixed with beer or wine. ${ }^{27}$

In chapter fifteen, which is entitled "Materia Medica", Preuss first discusses the plant remedies which the Talmud recommends as abortifacients, emetics, purgatives, digestives, etc., as well as various types of plasters, compresses, poultices, and bandages and the like, and their various medicinal ingredients. Also discussed are animal remedies such as honey, goats' milk, crushed pearl, animal dung and urine, and the great theriac. Non-medicinal remedies can be exemplified by the Talmudic suggestion that for abdominal pain, one should place warm clothes on the abdomen or a hot cup or bottle on the navel. Sunbathing is said to heal a variety of ailments. Certain foods should be avoided for certain illnesses. The final part of this chapter is 
devoted to a discussion of Jewish hospitals in antiquity or lack thereof and the visiting of the sick. The traditional Jewish concept of visiting the sick is that it is not a social call but a visit in which to help the patient by cooking or cleaning for him, or by assisting him in any other manner.

Chapter sixteen is very lengthy and deals with sex ethics in the Bible and Talmud. The subjects discussed by Preuss in this chapter are: chastity, marriage, procreation, genealogy in marriage, conjugal duties, cohabitation, impotence, unnatural coitus, coitus interruptus, abstention from procreation, times when cohabitation is prohibited, cohabitation and sexual desire, aphrodisiacs, the duda'im or mandrakes, conception sine concubito, proscribed marriages, punishment for incest, rarity of punishment infliction, the incest of Lot and his daughters, Amnon and Tamar, Levirate marriage, adultery, lustful thoughts, the sotah or suspected adulteress, rape, seduction, virginity, prostitution, the street of harlots, harlots in Biblical times, their skills, their attire and their hire, the jus primum noctis, Hegemonian coitus, masturbation, pederasty and homosexuality, transvestism, sodomy and bestiality, tribady and lesbianism.

In chapter seventeen, Preuss discusses the Jewish dietary laws, ritual slaughtering, and the Biblical prohibitions of blood and certain fat. He then describes the laws of ritual purity and impurity known as tumah and taharah of the human body, utensils, and clothing, and the rules of defilement relating to the temple, priests, cadavers, people afflicted with tzaraath and/or gonorrhoea, and the purification process including the ritual immersion. Even though these rules may serve a hygienic purpose, they are not meant to be "hygienic laws" but are divine commands. The importance of washing and bathing in ancient times is emphasized by Preuss.

Preuss also discusses death and dying in this chapter. In Jewish law, a dying person may not be touched or moved lest his death be hastened. The recognition of death requires the cessation of respiration and the absence of heartbeat. Furthermore, one must be certain that the person has not just fainted. The perfuming and embalming of the dead are then described. The five Biblical cases of suicide are mentioned including those of Saul, Ahitophel and Omri. Remarkable are the Biblical and Talmudic descriptions of marble and wooden coffins. Graves were either in the ground or in natural or man-made caves. Biblical and Talmudic discussions of the sepulchres of the patriarchs and of burial, cremation, and the decomposition of bodies, conclude this section.

The final chapter, entitled "Dietetics", deals with the rules which a healthy person should follow in order to avoid illness. Preuss asserts that dietetics refers not only to nutrition, as the modern usage of the word connotes, but also includes the entire mode of life of an individual, since residence and clothing and sports and work and many other things have certain influences on health, and hence belong in the word "diet". The ancient Greeks used the word "regimen" in the same context.

The general rules of health and nutrition, among others, are: eat moderately, eat simply, eat slowly and eat regularly. Chronic alcoholism, a rare disorder among Jews, is mentioned because of the juridical difference in Jewish law between shattuy (tipsy or fuddled) and shikkor (drunk or intoxicated). Regarding exercise, Rabbi Yohanan said: "do not sit too much, for sitting provokes hemorrhoids; do not stand 
too much, for standing is harmful to the heart (or stomach); do not walk too much, for [excessive] walking is harmful to the eyes". ${ }^{28}$

With regard to domicile, it is said that it is healthy to live in an open city, and harmful to live in a fortified or closed city. In the latter, houses are built close together, but in the former there are gardens and parks and the air is good.

\section{CONCLUSION}

How does one find words to emphasize the magnitude of Preuss's contribution to medicine and Judaica? I believe J. $O$. Leibowitz expresses it best as follows: “ . . . Preuss was one of the greatest Jewish historians of medicine; endowed with intimate insight in the field of early Hebrew medicine; outstanding in his critical approach, wide knowledge and unbiased honesty. Dear to our heart, his memory may serve as a shining and stimulating example for present and future historians". ${ }^{29}$

\section{REFERENCES}

1. Suessman Muntner, Introduction to the book of Asaph the physician, Jerusalem, Geniza, 1957, 174 pp. [Hebrew].

2. Harry Friedenwald, The Jews and medicine, Baltimore, Johns Hopkins University Press, 1944, vol. 1, pp. 99-145.

3. Ibid.

4. David Israel Macht, 'In memoriam-Dr. Julius Preuss', Johns Hopk. Hosp. Bull., 1914, 25: 277-279.

5. Suessman Muntner, 'Julius Preuss-father of Hebrew medical research', in J. Preuss' Biblisch-Talmudische Medizin, New York, Ktav, 1971, pp. vii-xii. Hirsch Leib Gordon, 'The centenary of the birth of Dr. Julius Preuss', Harofé Haivri, 1961, 1-2: 196-204 [Hebrew]. Suessman Muntner, 'Julius Preuss as a founder of research on the field of the ancient Hebrew history of medicine', Koroth, 1961, 2: 410-413 [Hebrew]. Joshua O. Leibowitz, 'Julius Preuss and the medico-historical research in Bible and Talmud', ibid., 414-425 [Hebrew] and i-iii [English].

6. Macht, op. cit., note 4 above. Karl Sudhoff, 'Julius Preuss (1914)' in Essays in the history of medicine, New York, Medical Life Press, 1926, pp. 351-353.

7. Muntner, 'Julius Preuss as a founder of research ... ' Leibowitz, op. cit., note 5 above.

8. Ibid., and Muntner, 'Julius Preuss-father of Hebrew medical research', op. cit., note 5 above.

9. Ibid.

10. J. O. Meller, 'My memories on Julius Preuss', in Essays in the history of medicine, op. cit., note 6 above, pp. 404-406 [Hebrew]. Karl Sudhoff, 'Julius Preuss', ibid., pp. 407-409 [Hebrew]. David Margalith, [Obituary] 'Dr. Yitzhak (Yulius) Preuss. Sept. 5, 1861 to Sept. 23, 1913', ibid., pp. 479-480 [Hebrew]. Suessman Muntner, 'Bibliographie der Schriften von Julius Preuss', ibid., pp. xiii-xv.

11. Leibowitz, op. cit., note 5 above.

12. Macht, op. cit., note 4 above.

13. Leibowitz, op. cit., note 5 above.

14. Muntner, 'Julius Preuss-father of Hebrew medical research', op. cit., note 5 above. Muntner, op. cit., note 10 above.

15. Sudhoff, op. cit., note 6 above.

16. Muntner, 'Julius Preuss, father of Hebrew medical research', op. cit., note 5 above. Muntner, op. cit., note 10 above. 


\section{Fred Rosner}

17. Julius Preuss, Biblisch-Talmudische Medizin, Jerusalem, Jewish National and University Library, Ms. Var. 443 非 13-14 pp 735.

18. Harry Friedenwald, 'Manuscript notes on Preuss', Jerusalem, Jewish National and University Library, Fr. 812B.

19. In preparing an English translation of Preuss's classic book, I, too, have found numerous minor errors. For example, in chapter 12, Preuss states that Tractate Negaim has ten chapters whereas in fact there are fourteen. In chapter 17 , he erroneously attributes a Talmudic statement to Rabbi Akiba instead of Rabbi Eleazar and, in chapter 6, Preuss does the reverse. In the first appendix to chapter 5, Preuss gives the dates of birth and death on Maimonides as 1131 and 1205. The correct dates are 1135 and 1204. In chapter 4, Preuss incorrectly speaks of the "daughter" of the Shunamite woman instead of her "son". He says the Hebrews have no word for coughing like the su'al of the Arabs; yet he overlooked the Hebrew word for cough which is she'ul. He says the yerakon and shiddaphon always occur together in Bible and Talmud. There is an exception, however, in Jeremiah 30:6. Numerous other minor errors of this nature could be cited. Furthermore, there are more than a score of incorrect bibliographic citations from Bible and Talmud (for example, Ecclesiastes 13:2 instead of 12:2 and Genesis 32:36 instead of 32:25). Numerous other examples could be cited. These amount, however, to less than a fraction of one per cent of the many thousands of references which Preuss quotes.

The inaccessibility of Preuss's classic book to the non-German reader has now been overcome with the imminent publication of an English translation.

20. Gordon, op. cit., note 5 above.

21. Ibid.

22. R. Rosenthal, 'The care of the sick in the Bible and the Talmud. Translated from Julius Preuss (1861-1913)', in S. R. Kagan (ed.), Victor Robinson memorial volume, New York, Froben Press, 1948, pp. 353-358.

23. Jacob Snowman, $A$ short history of Talmudic medicine, London, John Ball, Sons and Danielsson, 1935, $94 \mathrm{pp}$.

24. Sudhoff, op. cit., note 6 above.

25. Muntner, 'Julius Preuss-father of Hebrew medical research', op. cit., note 5 above.

26. Isidor Epstein (ed), The Babylonian Talmud, Tractate Hagigah, London, Soncino, 1938, p. 12.

27. Ibid., Tractate Shabbath, p. 536.

28. Ibid., Tractate Kethuboth, p. 718.

29. Joshua O. Leibowitz [editorial], 'Julius Preuss', Koroth, 1961, 2: 403.

\section{BIBLIOGRAPHY OF JULIUS PREUSS}

1. Ueber die Syphilis als Aetiologie der Tabes Dorsalis und der Dementia Paralytica. Inaugural Dissertation, University of Berlin, Berlin, A. Itzkowski, 1886, 30 pp.

2. 'Vom Versehen der Schwangeren; eine historisch kritische Studie', Berl. Klin. 1892-1893, 4-5 (Heft 51): 1-50. Also in Dt. Med-Ztg., 1892, 79: 924-926.

3. 'Zur Pathologie der Zunge', Zentbl. Chir., 1893, 20: 203-205.

4. 'Der Arzt in Bibel und Talmud: Eine historische Studie'. Virchows Arch. path. Anat. Physiol., 1894, 138: 261-283. Hebrew translation by Kahan published in Volume 1 of Ha-Measseph, (ed. Rabbinowitz), pp. 79-91.

5. 'Die Askara Krankheit im Talmud. Ein Beitrag zur Geschichte der Diphterie', Jb. Kinderleik, (New Series) 1895, 40: 251-257.

6. 'Zur Geschichte der Aderlasses', Wien. klin. Wschr., 1895, 8: 608-611, 625-629.

7. 'Neuere Arbeiten uber Biblisch-Talmudische Medizin', Israelitische Mschr., Berlin, 26 November, 1896.

8. 'Schriften uber Medicin in Bibel und Talmud. Ein Nachtrag nebst einigen Berichtungen zu Steinschneider's Artikel', Brody' Zt. Hebr. Bibliog., 1897, Vol. 2, Part 1, p. 22. 


\section{Julius Preuss}

9. 'Das Auge und Seine Krankheiten nach Bibel und Talmud. Eine historische Studie', Wien. med. Wschr., 1896, 46: 2151-2156, 2201-2203, 2245-2249, 2295, 2298, 23412343 ; and 1897, 47: 38-40, 79-82, 121-124.

10. 'Die Beschneidung nach Bibel und Talmud', Wien. klin. Rdsch., 1897, 11: 708-709, 724-727.

11. 'Die Mundhöhle und ihre Organe nach Bibel und Talmud', Dt. Med-Ztg., 1897, 18: 143144, 151-152, 169-170.

12. 'Die Mannlichen Genitalien und ihre Krankheiten nach Bibel und Talmud', Wien. med. Wschr., 1898, 48: 569-572, 617-619, 661-663, 709-712, 1193-1195, 1239-1240, 1285-1289.

13. 'Materialien zur Geschichte der Alten Medicin. Die Organe der Bauchhohle nach Bibel und Talmud', Allg. med. Zent Ztg., 1898, 67: 489-490, 502, 514-515, 526-527, 538-539, $551,564,575$.

14. 'Materialien zur Geschichte der Talmudische Medizin. Das Nervensystem', Dt. MedZtg., 1899, 20: 416-418, 428-430.

15. 'Nerven und Geisteskrankheiten nach Bibel und Talmud', Zt. Psychiat., 1899, 56: 107-137.

16. 'Materialien zur Geschichte der Talmudischen Medicin, Die Organe der Brusthohle', Allg. med. Zent Ztg., 1899, 68: 740-741, 752-753, 764-765, 777-778.

17. 'Materialien zur Geschichte der Talmudischen Medicin. Nase und Ohr', ibid., 1899, 68: 921-922, 970-971, 981-983.

18. 'Chirurgisches in Bibel und Talmud', Dt. Zt. Chir. (Leipzig), 1901, 59: 507-534.

19. 'Materialien zur Geschichte der Talmudische Medicin. Der Tote und seine Bestattung', Allg. med. Zent Ztg, 1902, 71:294-295, 306-307, 320-321.

20. 'Biblisch-Talmudischen Pathologie und Therapie', Zt. klin. Med. (Berlin), 1902, 45: 457-489.

21. 'Die Strafrechtliche Verantwortlichkeit des Arztes im Altertum', Munch. med. Wschr., 1902, 49: 489-490.

22. 'Die Medizin der Juden', in M. Neuburger and J. Pagel (ed.), Handbuch der Geschichte der Medizin, Jena, Gustav Fisher Verlag, 1902, vol. 1, pp. 110-118.

23. 'Malum Malannum', Med. Blatt. (Vienna), 1903, 26: 404-405. Reprinted in Jubilee volume honoring the 70th birthday of A. Berliner, Berlin, 1910.

24. 'Materialien zur Geschichte der Biblisch-Talmudischen Medicin. Die Erkrankungen der Haut', Allg. med. Zent Ztg., 1903, 72: 431-434, 455-457, 474-477.

25. 'Angina Lecunaris and Kali Chloricum (Vergiftungsfalle)', Dt. med. Ztg., 1903, 24: 447-448.

26. 'Waschungen und Bader nach Bibel und Talmud', Wien. med. Wschr., 1904, 54: 83-86, $137-140,185-188,327-329,397-400,439-442$.

27. 'Schwangerschaft, Geburt und Wochenbett nach Bibel und Talmud', Zt. Geburtsh. Gynäk., 1904, 53: 528-573.

28. 'Materialien zur Geschichte der Biblisch-Talmudische Medizin. XVI. Die Weiblichen Genitalien', Allg. med. Zent Ztg., 1905, 74: 96-98, 115-118, 135-137.

29. 'Die Pathologie der Geburt nach Bibel und Talmud', Z. Geburtsh. Gynäk., 1905, 54: 448-481.

30. 'Sexuelles in Bibel und Talmud', Allg. med. Zent Ztg., 1906, 75: 571-573, 589-592, 608-610, 625-627, 642-643, 659-661.

31. 'Prostitution und Sexuelle Perversitäten nach Bibel und Talmud', Mh. prakt. Dermat., 1906, 43: 271-279, 342-345, 376-381, 470-477, 549-555.

32. 'Biblische und Talmudische Bezeichnungen der Gesichtsfarbe' in Festschrift zum Vierzigjährigen Amts jubiläum des Herrn Rabbiners Dr. Salomon Carlebach in Lubeck. Berlin, Moritz Stern, 1910.

33. Biblisch-Talmudische Medizin. Beitrage zur Geschichte der Heilkunde und der Kultur Uberhaupt, Berlin, S. Karger, 1911, pp. 735. Reprinted unchanged by S. Karger in 1921 and again in 1923. Reprinted unchanged by Gregg International Publishing Co., 


\section{Fred Rosner}

Westuread, Farnborough, England, in 1969. Reprinted unchanged by Ktav Publishers, New York, in 1971, but with an introduction by Suessman Muntner and a register of Hebrew and Aramaic terms by Adolph Lowinger, translated and edited by Samuel Paley.

Unpublished Articles (Copies kindly provided to me by Mr. Jacob Preuss of Herzliya, Israel, son of Julius Preuss.)

34. 'Ueber Untersuchungen des Blutes zur Diagnostischen Zwecken', 1885.

35. 'Kurpfuscherei und "Geheimmittel"', 1893 (lecture delivered to the HandwerkerVerein, Berlin, 1893).

36. 'Frauenlob' (undated).

37. 'Eine Aufgabe fuer Juedische Aerzte' (undated).

38. 'Wohnungshygiene' (undated).

\section{NOTE}

Both Friedenwald and Muntner cite an anonymously written English article entitled "The Medicine of the Bible" published in Medical Magazine (London, Volume 23, No. 4, pp. 232-244, April 1914). According to Mr. Jacob Preuss (personal communication 31 August 1974), it seems highly unlikely that his father wrote this paper, since Preuss did not write in English and the article was published a year after he died.

The article entitled 'Ueber die Veranderungen der Zähne bei der Kierferrachitis des Schweiner' [concerning changes of the teeth in rickets of the jaw in the pig] published in the Archiv. fur Wissenschaftliche und Praktische Tierheilkunde (Berlin vol. 35, 非 6, pp. 561-581, Sept. 27, 1909) was written by a veterinarian, also named Dr. Julius Preuss. 